\title{
Thinking the fabrication of complex components in nowadays context
}

\section{SIGRADI2018 TECHNOPOLITICAS \\ xxii congresso da sociedade iberoamericana de gráfica digital 22th conference of the iberoamerican society of digital graphics 07|08|09|novembro|2018 iau usp | são carlos | sp br}

\author{
Elza Luli Miyasaka \\ Dep. Arq e Urb (DAU) - Viçosa Federal University | Brazil | mel@ufv.br \\ Ingrid Paoletti \\ ABC Dep - POLIMI | Italy | ingrid.paoletti@polimi.it \\ Márcio Minto Fabricio \\ IAU-USP | Brazil | marcio@sc.usp.br
}

\begin{abstract}
Thanks to the influence of innovative technologies is possible to build complex shapes using sophisticated software and digital equipment capable to work with a huge amount of data. The aim of this paper is to discuss the design and production from the fence panels of United Arab Emirates (UAE) pavilion at International Exhibition in 2015 and the Tower CityLife Milano from Zaha Hadid's office, in an attempt to understand how the customized components of the building walls were developed.
\end{abstract}

Keywords: Design for production; Design for manufacturing; Digital fabrication; Fabrication process; Mass customization.

\section{INTRODUCTION}

The civil construction has intensely lived the influence of innovative technologies, made it possible with the advances of industries and the contribution of information and communication tools. Thanks to this advances it is possible to build complex shapes through differentiated components, using sophisticated software and digital equipment capable to work with a huge amount of data. The aim of this paper is to discuss the design and production from the fence panels of United Arab Emirates (UAE) pavilion at International Exhibition in 2015 and the CityLife Milano Tower from Zaha Hadid's office, in an attempt to understand how the customized components of the building walls were developed.

According to Swab (2016), history has gone through three major industrial revolutions and is currently in a fourth movement called Industry 4.0. The process is considered transformative for the market and consumption of goods, and the relations between users, producers and communication technologies present an intimate relationship in the intelligent elaboration of customized products according to the needs of the users.

Industry 4.0 describes a project of autonomous systems of robotic factories and machines, using nanotechnology and additive production, connected in network and with the consumer. The production processes are decentralized in the places of consumption, with devices to evaluate performance problems, disseminating knowledge, and not only the product (LEE; KAO; YANG, 2014) (LASI et al., 2014) (LARIZZA, 2016) (TRENTESAUX, BORANGIU; THOMAS, 2016) (SOMMER, 2015) (SHAFIQA et al., 2015) (WANG et al., 2015).
Industry 4.0 has as main targets: 1. Produce in a customized way, attending more and more the needs of personalization of the objects according to the demand; 2 . Adapt manufacturing in a flexible way to meet the production chain; 3. Intelligently recognize information about network objects and machines; 4. Appropriation of the interaction with contemporary machines such as robots and autonomous machines and 5 . Suitability of offered services that contribute in the value chain (SHAFIQA et al., 2015).

To obtain the mass customization or advanced customization (NABONI; PAOLETTI, 2015), there is a need to the reduction of hierarchies and decentralization of commands; an intelligent logistics system to manufacture the product in different parts and powerful algorithms to manage internal and external information flows (ANTONIO, 2016). In the same way, more and more attention is focused on ecological and social contexts, causing industries to worry about issues related to energy efficiency and sustainability (LASI et al., 2014).

This configuration gives industries a high degree of autonomy, in which components acquire independent behaviors, process information, learning from it, and react in real time to self-control and organization. The network is open to establish new partners and create new models according to the costs and risks (ABRAMOVICI; GÖBEL; NEGES, 2015).

In this process, civil construction has also advanced to obtain products with advanced customization, in which the composition of its components is highly personalized. However, the industry usually does not pace the other consumer markets, adapting itself to slow process steps. 
According to OESTERREICH; TEUTEBERG (2016), the Industry 4.0 theme has not gained relevance in construction factories yet, especially when we talk about possible networks of connections between customers, production, data-feedback machines and specialized programming.

The concept of 14.0 for construction comprises a multiplicity of interdisciplinary technologies in order to allow the digitization, automation and integration of the construction process in all phases of the construction value chain. Several communication and information technologies are at different levels of maturity, such as BIM platforms (Building Information Modeling), which consist of an information processing system used from modeling, simulations, cost management, pre-fabrication solutions, energy consumption analysis, certification, postoccupation analysis, information management to the data clouds, which allow the development of the project in its various disciplines, with possibilities for sharing of processes and also the incorporation of mobile devices such as GPS verifiers used in earthmoving, drones, etc.

There are still a number of challenges; in order to fully reach the context of 14.0 in the construction sector, there is a need to address issues such as independent manufacturing platforms, increased levels of automation, improvements in production equipment for benefit from factory floor environments, components with better energy efficiencies and deployment of optical fibers to improve the internal and external communication capacity of manufacturing (LEONARD, 2015).

\section{METHODOLOGY PROCEDURES}

The strategy used for the research was the case study that has as characteristic to try to absorb the complexity of simple cases. It has a contemporary character, with little control or possibility of manipulation on the event, and is within its dynamic context. It works by collecting data with multiple combined methods, focused from different angles and then combined through triangulation to obtain valid results and consequent generalizations. Triangulation evidences a way of obtaining the validity of the case study, through the collection of combined data, in addition to other sources, theories and investigations. The combination of several information can often indicate different questions, which are positive for the research, since they show the network of variables that intervene in the problem (JOHANSSON, 2003).

For the production of this case study, it were analyzed drawings from the architecture office, plans, sections, elevations and details, the communication documents of manager project, coordinator project, manufacturing producers and the site documentations. In addition, interviews were made with key actors, as well as visits on site, and pictures of the manufacturing, construction, details and disassembling phase were analyzed. With this information, it was possible to understand the process of design and manufacturing of the complex components developed in UAE pavilion.

\section{CASE STUDIES}

Next, the research case studies will be presented, focusing mainly on the production process of the buildings, especially the sealing surfaces (envelope).

The design of UAE pavilion was developed by Foster \& Partners and had the concept of desert landscapes with the waves produced on the sand. These shapes were used in the texture of wall panels and in the path visitors (FOSTER \& PARTNERS, 2014). The pavilion was designed with metallic structure and closing with plates of GRC (Glassfiber Reinforced Concrete). There were several types of panels, some flat, others with cutouts, "U" shaped, with different dimensions, some curved panels and practically all of them with different drawings on the surface. The architecture office strategy was to make the side panels have always the same design and the lower and upper parts were also equal. This made possible to vary the position of the panels and its confection could be done from only one matrix model. This fact contributed that the mold was made on a large base and, from this matrix, the panels could change their position, producing different geometry.

Foster has created two types of panels: the flat external closing plates and the curved plates, which are along the 140-meter entry ramp. The ramp panels are unique pieces, with the curvature startled, and create a movement on the path traveled. For the design of these panels, the office used the Rhinoceros program and the Grasshopper plugin wave definition, as shown in figure 1.

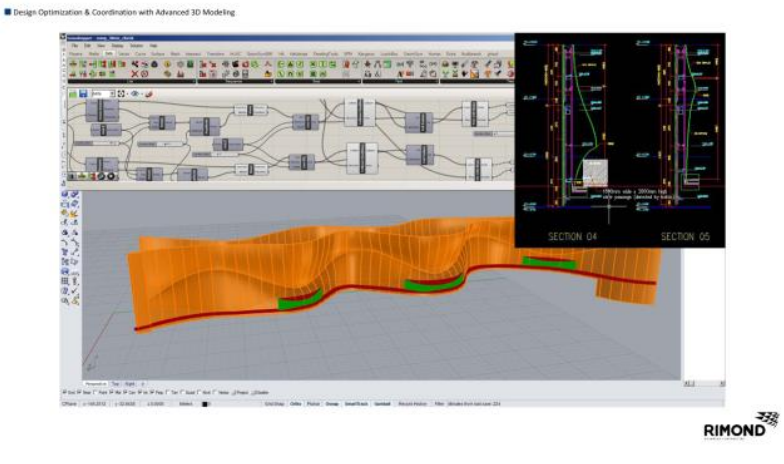

Figure 1: Adequacy of the curves of the panels, according to the human scale. Font: Rimond. Date: 2016.

The determining factors for the definition of the curves are the bottlenecks of the circulation corridor, the height of the visitors against accidents and the aesthetic aspect of the sand dunes. From this, patterns of modeling curves have been created, which can be higher or lower and their projection, more pronounced or not, defined by the path that resembles a canyon.

In manufacturing, the fact that the sides of the panels are identical contributed to the mold being formed on small segments of interchangeable shapes and, from these matrices, the molds produced in a milling machine can be changed position, producing different texture geometries. The molds were painted with epoxy resin paint, which gives the appearance of sand, and prepared to be reused up to 10 times, which means that, of the 930 panels, mass production was less than $10 \%$ of the whole. According to 

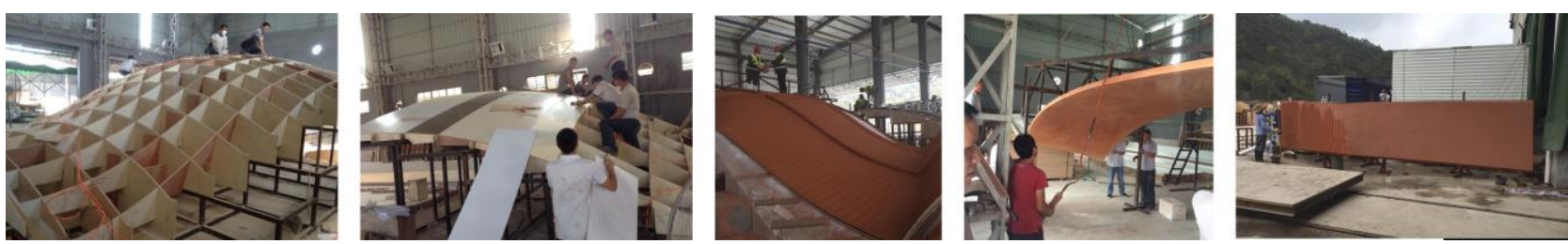

Figure 2: Production process of GRC panels with 1. Wood grate construction, 2. Coating with the texture of the panel, 3. Panel fabrication, 4. Sub-structure fixation and 5. Acid treatment to give appearance of sand. Font: Garry Tortona (Canbuild). Date: 2015.

the mill's producer, "the key to the final success of the panels was ensuring the perfect alignment of the ripples."

For the production of the ramp panels, which were $2.2 \mathrm{~m}$ wide by 7.5 to $10 \mathrm{~m}$ high, the negative molds curved in the vertical and horizontal directions, with a wooden structure, were built with a milling machine from a three-dimensional grid. It was necessary to use an electronic theodolite to control the curves. The connection between the panels has a design with fiting between each panel, which ensured the connection between them. In the last stage of the production for the finish, the panels were washed with acid to get a sand texture.

The use of computational tools was essential for the production of the panels, which ensured the precision and the production with specific design of the components. The architecture office forwarded the general concepts, which were adjusted to the $\mathrm{CNC}$ production machines and sent to the factory. The use of scanned equipments is innovative, allowing different configurations for the component, such as the production of this case.

The second research study is a corporate tower of the Zaha Hadid Archtects office which is part of an urban complex and is located approximately $5 \mathrm{~km}$ northwest of the central region, in the city of Milan-Italy.

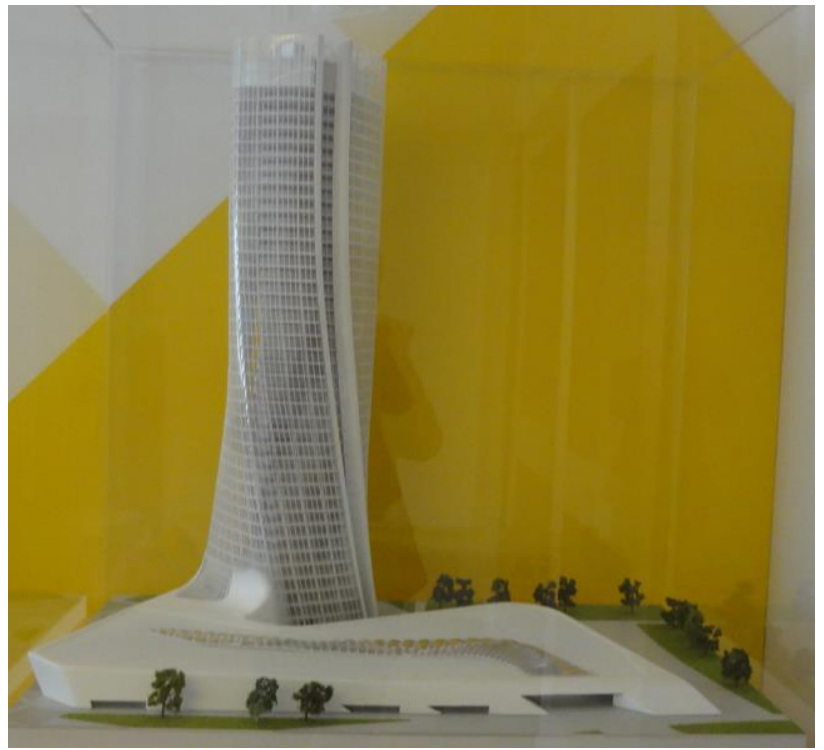

Figure 3: Model of the enterprise. Font: author. Date 2016.

The office tower was designed from plans of slabs whose twisting under the vertical axis is controlled algorithmically, so that each floor has an angle related to the upper and lower floors, bringing dynamism to the building. With 170 meters of height, 44 levels and $67,000 \mathrm{~m} 2$ of constructed area, it has two double-skinned glass faces that surround the building, and two slits between the faces that run through the surface from the base to the top and are covered by panels of aluminum, that leave the zero level of the building and follow the twist.

The elaboration of the surface of $15.000 \mathrm{~m} 2$ has conformation with double glasses and was projected in independent planes, like two separate skins. The sealing surface of the tower is basically composed of glass and steel; the cells were individually drawn with a glass plate and its miter.

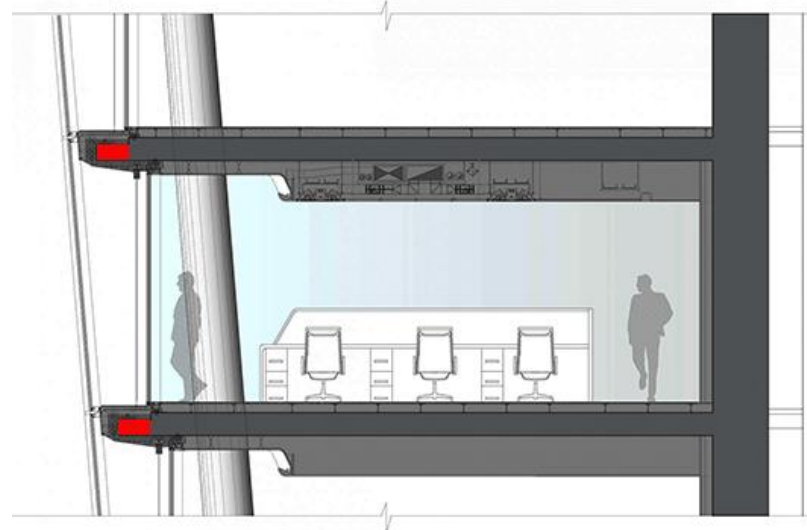

Figure 4: Level cut with expansion of the slab for external skin fixation. Font: Arup Milan, Francesco Catalano Architect. Date 2016.

The outer skin defines the distorted shape of the building; it's generated by an algorithm in which, geometrically, the model is always under control of the dimensions of the panels, the orientation, torsion, the degree of insolation, etc. The office that developed the project makes use of Rhinoceros programs with a Grasshopper plug-in, Catia (Computer Aided Three-Dimensional Interactive Application), developed for the manufacturing sector and engineering, created by Dassault Systèmes, and the SolidWorks program, also of Dassault Systèmes, one of the oldest and is used for 3D modeling in the mechanical engineering sector, in other engineering and manufacturing.

The geometry of the surface is created from a conceptual design of the office of architecture. From this, the office responsible for the project analyzes the best geometry and the best way to parameterize this surface according to the authors' instructions, incorporating the needs of environmental comfort, openings requirements, ventilation, etc. For its elaboration, it is necessary to satisfy the requirements of architecture, structures and substructures and the requirements of the facade, which are determined by the given geometry parameters. In meeting these 
requirements, the preliminary indicators for the development of connection and fitting designs are defined.

With simple laminated glass, irregular, variable in size and inclination, these are deformed according to the twist of the building. The angle of inclination of the glass can vary, on the same level, in negative, zero or positive degree. It was necessary to carry out studies of the dynamics in the 44 levels and to create specific technological solutions.

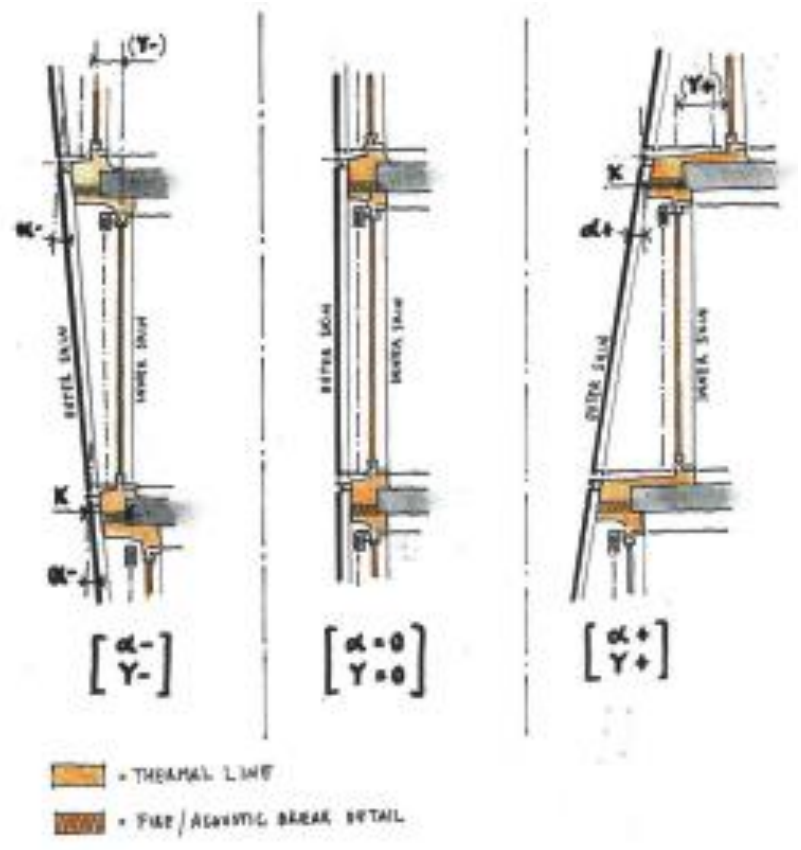

Figure 5: Explanatory sketch of the external skin angles. Font: Arup Milan, Arch. Francesco Catalano. Date: 2016.

The inner skin is a standard facade with a conventional, flat structure, with vertical frames of the same size, supported on the slab, which can be assembled quickly, without major complexities. The distance between inner and outer skin varies in plan and in cut across the periphery of the building.

With this artifice, the technicians obtained the double layer of glass, which keeps its advantages of comfort, and solved much of the problems with the configuration of the rotation of the external surface. The research has no data on how much this strategy has optimized the costs of designing, assembling and using materials, but it is clear by showing how design solutions can benefit the different aspects of building development.

The outer surface has no function of waterproofing and thermal protection and is responsible for the entry of air between the two surfaces; the skin is a barrier to the inner surface that meets all these requirements. The extension of the slab that receives the external skin was also important to meet the fire norms and theoretical analyzes with study systems of laboratory reference on the temperature and pressure of ventilation between the two glasses. Between the two layers of glass, there is a small terrace, accessible for maintenance and cleaning. A door in the level of the floor makes the access to the interior of the two glass planes.
Generally, in very complex projects, such as the Hadid Tower, several offices are hired for the development of each project, such as facade, structure, mechanical engineering, among others, which are responsible for making feasible in relation to budget, development drawing, production and assembly. The designs for the production are composed by elevations, plants, cuts, levels, dimensions, materials, fixing points and interface details. Structural calculations, thermal comfort, and other projects are submitted as part of the construction design process.

The work of the firm that proposed solutions for the tower's double glass skin found brilliant solutions for the object's viability, thanks to small modifications in the original design that completely altered the final result, directly interfering with investments, component manufacturing and Assembly. These solutions are:

1. extension of the slab, which made possible the separation between the two planes;

2. placement of the tower twist only on the outer glass plane;

3. internal plane seal with conventional, rectangular and identical window frames;

4. plates of laminated glass with forced cold curve, which will be discussed below,

5. natural ventilation system between the two planes, meeting the fire regulations.

The designs for the manufacture are usually internal spreadsheets, subdivided into parts for cutting, parts for welding and finishing. They indicate the requirements of the profiles, cutting measures, details for preparation of the work, assembly of the components, fabrication of elements and details of requisition of materials. All the designs for the manufacture of the components are prepared, submitted, approved as a priority according to the relevance of the activities.

The panels are manufactured in individual trapezoidal cells, with different stresses in the substructure. Perhaps only at the top of the building the efforts applied on the scaffold and in the glasses are practically zero, due to its design being close to the orthogonal. The behavior of a piece in trapezoidal shape is completely different from that of a rectangular piece because it creates diagonal forces on the substructure.

The outer panels in the first 10 levels are tilted between 15 $\mathrm{cm}$ or $20 \mathrm{~cm}$ and have been designed specifically for their location with a steel frame and waterproofing system. The degree of obliquity varies with the height of the building. In the upper plane, the panels are close to the rectangle, but, at the base of the tower, the obliquity increases progressively. The maximum angle of deflection of the cold glass is $3 \mathrm{~cm}$ at each end for these dimensions of the plate, which refer to the maximum behavior of the glass according to its stress level.

With the exception of places where the curvature is bigger, all other glasses are flat, with curvature produced at the factory. In order to find these solutions, several proposals of geometry were made, in order to seek answers to all the questions. As the coordinating architect of the project quotes, "The solution may not be the best, but it is the most appropriate in the context" (CATALANO, 2016). 
For the production of the hot bend, the glass is heated and is subsequently placed on a mold. This technology, in addition to being much more expensive, changes the color of the material. The outer skin panels in the connecting zone are hot curved glass panels with the geometry of a cylinder and slanted cut plates. The angle of the amount of the inner skin is usually uniform, but there are some points of discontinuity in correspondence with the transition zone.

In the development of the projects of the analyzed cases, it was verified that the works were meticulous and, with the help of programming and association with the application of algorithms, it was possible to design and describe each cell, with its due dimensions and specificities, as well as the processes to be carried out at the construction site for the correct installation and to obtain the expected results.

\section{DISCUSSION}

In the face of these analysis of civil construction and its context within the digitized world and proposed by the industry 4.0, it is considered that the sector has made use of the digital tools, mainly in relation to the development of projects that require a large amount of data, in the development of building automation devices and in the association of several companies with distinct abilities to be maintained in the competitive and diversified market. However, it's seen that the network formed between consumers with direct devices linked to the industry, as advocated by policies to encourage digitization, may not yet apply to the sector, given the specific variables such as cost, durability, scale and others.

To plan the production of components in design phase is essential for their optimization, with regard to costs, use of materials, time, logistics and installation. Thinking about the viability of panels production always has the intention to realize the largest number of equal and flat components, even if the digitalized equipment is able to manufacture parts with high complexity. The strategy used to produce the advanced customization components provided agility in manufacturing of the components, economy to fabricate molds, economy of space, time and production.

\section{ACKNOWLEDGMENTS}

We thank ActLab Research Group, ArquiTec Research Group, to Coordenação de Aperfeiçoamento de Pessoal de Nível Superior - CAPES _ PDSE process no. 99999.003519/2015-05 and support for the dissemination of research to Post Graduation Program and Architecture and Urbanism Departament of Federal University of Viçosa MG (UFV).. Rimond Office of Design Manage and Development, Eng Giuseppe Chiarandá, Ramboll Office of Design Manage and Development, Also to Researcher Roberto Naboni, Maya Zheilazkova, Arq. Ommer Mert Cek, Eng. Roberto Ferrari, Eng. Gary Tortona, Arq. Francesco Catalano e Arq. Bernardo Jacobsen.

\section{REFERENCES}

ABRAMOVICI, M.; GÖBEL, J. C.; NEGES, M. (2015). Smart Engineering as Enabler for the 4th Industrial Revolution, In:
FATHI, M. (Ed.) Integrated Systems: Innovations and Applications, Siegen: Springer. p. 173-194.

ANTONIO, D. (2016). Personalizzazione di Massa - La Diffusione dell'Internet delle cose Permetterà alla Manifattura di Accendere un Dialogo Continuo tra Prodotto, Machina che lo Fabbrica e Consumatore Finale. Milano: Nòva Edu - Lezione di Futuro - 07, II suo 24 ore.

CATALANO, F. (2016). Complex Surface: City Life Tower. (E. L. Miyasaka, Entrevistador, Autor, Tradutor) Milão, Lombardia, Itália.

FOSTER \& PARTNERS. (2014). The UAE Pavilion at Expo Milano 2015: Detail Design. Milano: General Descriptive Documentation.

JOHANSSON, R. (2003). Case Study Methodology. International Conference Methodologies in Housing Research Stockholm: International Conference Methodologies in Housing Research. p. 22-24.

LARIZZA, A. (2016). La Rinascita della Fabrica: Nell'era della Manifattura Digitalizzata, Le Aziende Possono Tornare a Creare Valore a una Condizione: L'uomo dourà Competere al Fianco delle Machine In: La Fabrica Digitale: Come Funziona L'Industria 4.0 e che cosa Possiamo Fare. Milano: Nòva Edu - lezione di Futuro - 07, II suo 24 ore.

LASI, H. L.; KEMPER, H.-G.; FETTKE, P.; FELD, T.; HOFFMAN, M. (2014). Industry 4.0. Business \& Information Systems Engineering, v.6,n.4, p.239-242.

LEE, J.; KAO, H.-A.; YANG, S. (2014). Service innovation and smart analytics for Industry 4.0 and big data environment. Procedia CIRP, v.16, p. 3-8.

LEONARD, J. (2015). Building Tomorrow's Delivering the benefits of Industry 4.0 requires robust communication. Professional Engineering, v.28, n.2, p.16.

NABONI, Roberto \& PAOLETTI, Ingrid (2015). Advanced Customization in Architectural Design and Construction. Milano: Springer.

OESTERREICH, T. D.; TEUTEBERG, F. (2016). Understanding the implications of digitisation and automation in the context of Industry 4.0: A triangulation approach and elements of a research agenda for the construction industry. Computers in Industry, v.83, p.121-139.

PAOLETTI, Ingrid. (2006). Construire le forme Complesse: Innovazione, industrializzazione e transferimento per il projetto di architecttura. Milano: Libreria CLUP.

SHAFIQA, S. I.; SANINA, C.; SZCZERBICKIB, E.; TOROC, C. (2015). Virtual Engineering Object/virtual Engineering Process: A specialized form of Cyber Physical System for Industrie 4.0. Procedia Computer Science, v. 60, n.1, p. 11461155.

SOMMER, L. (2015). Industrial revolution - industry 4.0: Are German manufacturing SMEs the First Victims of this revolution? Journal of Industrial Engineering and Management, v. 8, n.5, p.1512-1532.

SWAB, K. (2016). The Fourth Industrial Revolution, New York: Crown Business.

TRENTESAUX, D.; BORANGIU, T.; THOMAS, A. (2016). Emerging ICT concepts for smart, safe and sustainable industrial systems. Computers in Industry, v.6, n.4, p. 1-10.

WANG, S.; WAN, J.; ZHANG, D.; LI, D.; ZHANG, C. (2015). Towards smart factory for Industry 4.0: A self-organized multiagent system with big data based feedback and coordination. Computer Networks, v.101, p. 158-168. 